Note: This is the accepted version of the following article: Keuleers, F. (2015). 'Explaining External Perceptions: The EU and China in African Public Opinion'. Journal of Common Market Studies, to be published in final form at http://onlinelibrary.wiley.com/journal/10.1111/\%28ISSN\%291468-5965.

\title{
Explaining External Perceptions: The EU and China in African Public Opinion
}

\author{
Floor Keuleers ${ }^{1}$ \\ LINES Institute, University of Leuven
}

\begin{abstract}
While the past decade has seen a remarkable growth in research on external perceptions of the EU, this literature remains characterized by three important gaps: highly uneven geographical coverage, lack of comparisons between the EU and other actors, and a near-exclusive focus on description to the detriment of explanation. This article introduces a novel explanatory framework for perceptions research and applies this to popular perceptions of the EU and China in 19 Sub-Saharan African countries, shedding light on a neglected dimension of the 'traditional' versus 'emerging donors' debate. It finds, first, that China has quickly succeeded in becoming more well-known among African populations than the EU. Second, popular perceptions do not reflect the antagonism pervading the discourse on 'emerging donors', with both the EU and China enjoying broad-based popular support. Finally, preferences are a function primarily of individual experiences and outlooks, refuting earlier claims on the importance of national-level factors.
\end{abstract}

\section{Introduction}

The study of the way the European Union is perceived in third countries has over the last decade rapidly become a blossoming field of research. Scholars active in this field -while employing different geographical, theoretical and methodological approaches- are united by an intention to go beyond the 'excessively Eurocentric perspective' that frequently characterizes existing analyses of the EU's international role (Lucarelli, 2014, p. 11). By zooming in on the views of those who are at the 'receiving end' of the EU's international actions, the external perceptions literature seeks to complement this dominant perspective and to inject a reinforced relevance into the study of EU foreign policy. Studying external perceptions, it is argued, will offer a welcome check on narratives of the EU as a unique international actor, is a source of insight into the effectiveness of EU foreign policy, and can shed light on one of the constitutive elements of the EU's international identity (Kelly \& Smith, 2013, p. 220; Lucarelli, 2014, pp. 1-2).

\footnotetext{
${ }^{1}$ The research for this article was made possible by a PhD Fellowship of the Research Foundation Flanders (FWO). I am grateful to the three anonymous reviewers for their insightful comments and suggestions.
} 
Despite the rapid development of this field of study, major gaps still remain in the analysis of the external images of the EU. This article seeks to tackle three such gaps. First, its geographical focus is on Sub-Saharan Africa, a region for which perceptions have remained markedly underexplored. Second, the article introduces a much-needed comparative perspective, contrasting African perceptions of the EU with those of China, the most prominent of the 'emerging players' on the continent. Lastly, it goes beyond the so far dominant focus on description, by presenting a framework of explanatory variables and applying this to the case at hand through a multilevel analysis of Afrobarometer data covering 19 countries.

The first part of the article reviews the scarce evidence on African perceptions of the EU. The following section argues why it is crucial to compare perceptions of the EU to those of other players, for both empirical and analytical reasons. Section three then delves deeper into explaining perceptions, highlighting the neglected issue of multiple levels of explanation and constructing a novel explanatory framework. The research questions and methodological choices are presented in section four, after which section five presents the analyses and discusses the main findings.

\section{African perceptions of the EU: a blind spot in the literature}

A first shortcoming of the existing literature on external perceptions of the EU is its patchy geographical coverage. While several authors have attempted to achieve a diverse selection of countries and regions (e.g. Elgström, 2007; Lucarelli \& Fioramonti, 2010), the literature has so far predominantly looked at various parts of Asia and the Pacific (Chaban \& Holland, 2013; Chaban \& Magdalina, 2014; Stumbaum, 2013) and at the BRICS countries (Chaban \& Elgström, 2014; Kelly \& Smith, 2013; Mayer \& Zielonka, 2012; Torney, 2014). As a corollary, many other countries have remained understudied. Notably rare are studies on African perceptions of the EU, a remarkable observation given the long history of co-operation between the two continents. As Sub-Saharan Africa is the destination of major EU financial resources -a fact that has given rise to an ever-changing sequence of co-operation paradigms- the region would appear to be a key arena for analysing the EU's external image.

In practice, however, extremely little is known of how Africans perceive the EU. Studies have been very scarce and mostly elite-focused ${ }^{2}$ (Elgström, 2010; Sicurelli, 2010). A downside of such elitecentred approaches is that the resulting analyses risk insufficiently going beyond standard accounts of the relationship and its main bones of contention. Research focusing on the perceptions of broader sections of society has been limited to two countries: Kenya and South Africa (Fioramonti \& Kimunguyi, 2011; Fioramonti \& Olivier, 2007; Fioramonti \& Poletti, 2008; Olivier \& Fioramonti, 2010). South Africa is typically discussed in the context of the BRICS, reflecting the fact that it can hardly be considered a typical case. The small number of cases has put constraints on the questions and hypotheses that could be addressed, and is particularly salient for the issue of multiple levels of

\footnotetext{
${ }^{2}$ The perceptions literature typically makes a distinction between four types of external perceptions: public opinion, news media, civil society, and political and economic elites.
} 
explanation introduced below. Needed, therefore, are analyses of African perceptions of the EU including a much larger set of countries.

\section{The need for a comparative perspective}

A second gap in the perceptions literature concerns the lack of comparative analyses. Perceptions of the EU have been studied in isolation, an approach that does not reflect the EU's actual status as an international actor. Third countries are generally faced with a varied and sometimes increasing set of potential partners, making it far more meaningful to compare perceptions of the EU to those of others relevant actors (see also Lucarelli, 2014, p. 12).

Such a comparative design is particularly relevant for the case of Africa, where the (re-)emergence of new players has become a hotly debated topic for academics and practitioners alike. This reemergence is not only presented in terms of competing economic or security interests, but as a competition between alternative models of development vying for the preference of African elites and populations. 'China's model', it is argued, 'serves as a credible alternative with regard to Africa's development and political economic reforms' (Men \& Barton, 2011, p. 11). It is, therefore, remarkable that systematic inquiry into African perspectives on these different approaches has been absent. African evaluations have mostly been discussed in an anecdotal fashion (for two empirical works, see Fioramonti \& Kimunguyi, 2011; Hanusch, 2012), leading to widely diverging conclusions. On the one hand, media sources often state that only African elites favour China over traditional donors, as China's lack of conditionality allows them more leeway (Sautman \& Yan, 2009). In contrast, it has also been asserted that 'one can see why the gradualist reform and experimental pragmatism modelled by the Chinese are attractive to African people - not just corrupt leaders and elites' (Mawdsley, 2008, p. 521). A systematic study of African evaluations has, however, not yet been carried out.

In addition to becoming more attuned to reality, the EU perceptions literature could also benefit from a comparative perspective on an analytical level. At present, different literatures on perceptions are developing independently from each other, without the interaction that could breathe new life into existing debates. Particularly relevant for the case under study is the growing body of work on how African public opinion perceives China or 'the Chinese', which has already achieved a much broader geographical coverage than similar work on the EU. Its focus has varied from a narrower one on Chinese immigrants to more encompassing discussions of China's presence as a whole. Most studies have adopted a single case study approach (see Esteban (2010) for Equatorial Guinea; Park (2013) for South Africa and Lesotho; Shen and Taylor (2012) for Uganda; Sylvanus (2013) for Togo). Larger-N studies have been less common (Hanusch, 2012; Sautman \& Yan, 2009).

There has been a complete lack of attempts to build bridges between this emerging field of research and the burgeoning literature on external perceptions of the EU. ${ }^{3}$ This article aims to illustrate that such bridges could nevertheless prove analytically fruitful. Research on the EU's external image has

\footnotetext{
${ }^{3}$ In contrast, Misík has recently embedded the literature on the EU's external image within older schools of thought on US foreign policy (2013).
} 
developed out of discontent with the inward-looking character of much work on EU foreign policy. The new field of research has, however, remained firmly rooted in this existing literature, sometimes resulting in a very 'European' take on what the outside world thinks of the EU. A prominent example hereof is the tendency to discuss the EU's external image in terms of its normative power status (Bacon \& Kato, 2013; Chaban, Elgström, Kelly, \& Lai, 2013; Jain \& Pandey, 2013; Larsen, 2014). The initial question of how others see the EU then risks becoming confined to a sui generis assessment of whether or not others perceive the EU as the EU wants to be perceived. Developing stronger links with bodies of literature on perceptions of other international actors could be a step in opening up the focus of inquiry and formulating more general questions and hypotheses.

\section{Going beyond description}

One concrete contribution from the literature on African perceptions of China is to be found in its more explanatory approach. Thus far, research on EU perceptions has been mainly descriptive. As pointed out by Lucarelli, 'the existent literature already makes an attempt to identify the factors that influence perceptions by embedding the images presented in the specific relations between the EU and that specific country', but 'the issue has not been theorized in such a way that a relation between different factors could be identified' (2014, p. 12). The framework proposed by Tsuruoka (2008) and its revision by Chaban and Magdalina (2014) constitute the two main attempts at explanation. However, both focus on elite perceptions, and hence assume extensive knowledge of relations with the EU on the part of respondents. Discussions of public opinion, in contrast, are usually limited to summary statistics, detailing which proportion of the public knows the EU or evaluates it positively. In contrast, the literature on African perceptions of China has made progress in studying how groups within countries differ from each other, and which factors can explain perceptions.

\section{Multiple levels of explanation}

Even the literature on African perceptions of China, however, has neglected an important preliminary issue. This concerns the level at which explanation is to be situated and studied. While rarely explicitly tackled by researchers ${ }^{4}$, this question has crucial theoretical and methodological implications. In essence, there is a divide between two approaches to studying perceptions. The first focuses on differences in average perceptions between countries, and is thus consistent with the idea that perceptions are mainly determined by country-level factors. These may include general characteristics of the country itself, of its international relations, and of political or media discourses at the national level. In this vein, Sautman and Yan concluded that 'the dominant variation in African perspectives [on China-Africa links] is by country, compared with variations such as age, education and gender' (2009, p. 728).

The second approach focuses on explanatory variables situated at a lower level, assuming that perceptions are primarily influenced by characteristics of individuals, their day-to-day experiences, and beliefs and attitudes. For the sake of clarity and brevity, this article uses the term 'individual-level

\footnotetext{
${ }^{4}$ For an important exception, see Chaban and Magdalina (2014).
} 
factors'. It should be noted, however, that these characteristics are often not purely individual, but rather (partly) shared within a variety of smaller social groupings. An illustration of this focus can hence be found in the work of Esteban on Equatorial Guinea, in which the author argues that 'acute divergences emerge among different strata of Equatoguinean society in their evaluation of the increasing links between their country and China' (2010, p. 248).

The issue of multiple levels of explanation is part of a larger conundrum, which is central to the study of external perceptions but has received limited attention. This is the question of exactly which dynamics are being captured by 'external perceptions' (and the various operationalizations of this term). Rather than merely a matter of definitions, this question has important implications for the justifications for perceptions research. Thus far, these have been mostly of an intuitive nature. ${ }^{5}$ They can be summarized as follows: "perceptions can act as a fruitful resource to systematically evaluate the $\mathrm{EU}$, providing insight into the effectiveness of EU international action from the perspective of outsiders' (Kelly \& Smith, 2013, p. 220). Such statements are, however, dependent upon important assumptions regarding how perceptions come about and what exactly it is they capture. As illustrated by the discussion of multiple levels of explanation, this aspect of perceptions cannot be taken for granted, especially for the case of public opinion ${ }^{6}$. Popular perceptions may reflect an international actor's impact on the lives of individuals, but may also simply echo discourses formulated by national elites, or be influenced by other factors that have not yet received attention. A more thorough reflection on the origins of (popular) perceptions is thus needed, in order to substantiate claims on what perceptions research can contribute to the study of international relations and foreign policy.

\section{Towards a framework for explanation}

This article contributes to such a reflection by constructing a framework of explanatory variables, thereby paying particular attention to the issue of multiple levels of explanation. To achieve a more comprehensive framework, hypotheses are drawn both from work on perceptions of the EU and China and from the more general literature on EU-Africa and China-Africa relations.

For both the national and the individual level of explanation, two types of variables are discussed. On the one hand, general characteristics of countries and individuals may have an impact on perceptions of an international actor. On the other hand, perceptions may be influenced by the relationship with

\footnotetext{
${ }^{5}$ See Torney (2014) for a more critical assessment of the relationship between external perceptions and EU foreign policy effectiveness.

${ }^{6}$ Arguments on the rationales for studying perceptions could also benefit from an explicit distinction between the different types of studies. EU foreign policy effectiveness, for instance, might be impacted more by elite perceptions than by public opinion. In contrast, when connecting the perceptions literature to ideas on 'Normative Power Europe' (see e.g. Larsen, 2014), it seems appropriate to look at all types of perceptions.
} 
that particular actor. ${ }^{7}$ The resulting explanatory framework, which is presented in Table 1 , thus consists of four categories. ${ }^{8}$

Table 1: Explaining African perceptions of development partners

\begin{tabular}{|l|l|l|}
\hline \multicolumn{1}{|c|}{$\begin{array}{l}\text { Country level } \\
\text { characteristics }\end{array}$} & $\begin{array}{l}\text { Level of economic development } \\
\text { Type of political regime }\end{array}$ & $\begin{array}{l}\text { Politicisation of the relationship as an electoral } \\
\text { issue by national politicians } \\
\text { Media messages } \\
\text { Historical relationship with the partner } \\
\text { Current trade and investment relations with the } \\
\text { partner } \\
\text { Current aid/development relations with the } \\
\text { partner }\end{array}$ \\
\hline $\begin{array}{l}\text { Individual level } \\
\text { characteristics }\end{array}$ & $\begin{array}{l}\text { Socio-economic status } \\
\text { Occupation } \\
\text { Urban vs. rural area } \\
\text { Importance attached to democracy } \\
\text { Importance attached to civil-political human } \\
\text { rights } \\
\text { Viender on donor influence } \\
\text { Importance attached to infrastructure }\end{array}$ \\
& $\begin{array}{l}\text { Age } \\
\text { Education }\end{array}$ & \\
\hline
\end{tabular}

Analyses of African perceptions of China have dedicated considerable attention to relation-specific characteristics at the country level. Based upon a survey of university students and staff in nine African countries, Sautman and Yan concluded that variation in perceptions is mainly located at the country-level. They further argued that since the nature of countries' interactions with China is fairly similar across Africa, variations in perceptions 'are primarily a function of the extent to which national politicians have elected to raise "the Chinese problem" and, secondarily, the extent of Western media influence in African states' (2009, p. 728).

Questioning these authors' assertion that bilateral relations are too uniform to explain variation in perceptions, Esteban argued that 'the historical relation between China and each individual African country mediates the African citizens' assessment of the current Chinese presence on the continent' (2010, p. 234). Similarly, Park focused on the role of historical ties and national memory in explaining differing perceptions of the Chinese in South Africa and Lesotho (2013). Complementing such work on historical ties, Hanusch looked at contemporary trade and investment relations, finding evidence for a relationship between higher levels of imports from China and less favourable attitudes towards China's presence. His analysis also mentioned the potential impact of Chinese development aid, but was unable to include this factor due to the lack of reliable data on Chinese aid (Hanusch, 2012).

Less attention has gone to general characteristics at the country level, such as the level of economic development or the type of political regime. It seems plausible, however, that such characteristics also

\footnotetext{
${ }^{7}$ This is related to Tsuruoka's distinction between exogenous (emanating from the EU itself) and endogenous (operating within the third countries) sources of perceptions (2008, pp. 9-10). The framework presented here, however, reflects the view that many variables of interest are embedded within the relationship between actors, rather than exclusively attributable to one of them.

${ }^{8}$ Rather than claiming exhaustiveness this table seeks to indicate some of the main axes along which explanatory variables can be positioned.
} 
influence perceptions of international actors. More specifically, they might fulfil an intermediary role, reducing or enhancing the effect of other explanatory variables.

At the individual level, both general and relation-specific characteristics have received attention within the China-Africa literature. Regarding general characteristics of individuals, the most common argument focuses on individuals' socio-economic position, as this mediates how people experience the Chinese presence. An oft-heard yet simplistic version of this argument identifies a binary between a ruling elite (allied to China) and the majority of the population (Sautman \& Yan, 2009, p. 734). A more sophisticated account differentiates between the perceptions of consumers, small entrepreneurs, businessmen and landlords (Esteban, 2010). A related variable that has not yet received attention is whether respondents live in an urban or a rural area, as this also influences whether and how they encounter particular international actors.

Another relevant characteristic at the individual level is respondents' media consumption. Shen and Taylor found for Ugandan youths that 'the more reliant on local media the respondents are, the more they worry about their personal insecurity in the wake of China's expanding economic role' (2012, p. 708). In contrast, Hanusch found a positive yet weak relationship between evaluations of China's engagement and the frequency of obtaining news from radio, television and newspapers (2012).

The relationship between perceptions and more basic individual characteristics has also been studied. Age does not appear to have a clear impact on perceptions of China. The role of education remains subject to debate. Shen and Taylor found a highly significant positive correlation between a lower level of education and the perception that Chinese workers have taken away Ugandan jobs (Shen \& Taylor, 2012). Other studies, however, did not find a consistent influence of education (Hanusch, 2012; Sautman \& Yan, 2009). The effect of gender has been less ambiguous, with women consistently expressing more negative perceptions of China than men (Hanusch, 2012; Sautman \& Yan, 2009).

While such general characteristics of respondents have been studied fairly extensively, relationspecific individual characteristics have received less attention. This fourth category is nevertheless highly interesting, as it deals with how perceptions are influenced by attitudes on topics of direct relevance to the relationship with a particular actor. Hanusch carried out the most systematic study of such factors, finding strong evidence that respondents who attach major importance to civil and political human rights have significantly more negative perceptions of China (2012).

This article introduces two additional hypotheses on relation-specific individual characteristics, drawn from the literature on traditional versus emerging development partners. First, one of the most noted features of the Chinese engagement with Africa is the absence of political conditionality, which sets it apart from traditional OECD-DAC involvement (Brautigam, 2011; Mawdsley, 2012). Therefore, it is hypothesized here that African citizens who feel that international donors have too strong an influence on their government will have a stronger preference for China. The second hypothesis is related to China's focus on infrastructure development, which has for several decades been quite marginal in the aid of traditional donors. As stressed by Ogunleye, 'physical infrastructure development remains the most important engagement through which Chinese presence could be felt in Africa' (2011, p. 227). It has been speculated that this high visibility of infrastructure support makes it an important factor in the 
creation of (positive) African perceptions of the Chinese engagement (Holslag, 2011, p. 5). It is expected, therefore, that respondents who see infrastructure development as a priority will express a stronger preference for China.

In summary, the literature on African perceptions of China has made far stronger progress in explaining perceptions than its EU-focused counterpart. Efforts are still fragmented but can feed into an explanatory framework with more general applicability, especially when combined with insights from other relevant sets of literature. The following sections present an empirical exploration of the resulting framework.

\section{Methodology}

In order to move beyond the three shortcomings of the perceptions literature outlined earlier, this article addresses the following research questions:

1) How do African populations evaluate the contribution to development of the European Union?

2) How does this compare to their evaluation of China's contribution?

3) Which level, i.e. the national or the individual level, is most important in accounting for variations in these perceptions and preferences?

4) Which (general or relation-specific) variables can account for variations in preferences?

The analysis is based upon a quantitative comparative approach including 19 countries in Sub-Saharan Africa $^{9}$, as this allows for studying the impact of both national-level and individual-level variables. While the countries constitute a varied group in terms of GDP per capita, colonial history and geographical location, there is a lack of Central-African countries, since instability in the region has hindered systematic data collection. Data was taken from Round 4 of the Afrobarometer survey (conducted in 2008), which to date remains the only large-scale source of information on how African populations evaluate the development support of several international actors ${ }^{10}$. As China's engagement with Africa (re)gained momentum after the year 2000 (and especially after 2006), the data capture African popular perceptions at a fairly early stage. The Afrobarometer surveys are based upon randomly drawn national probability samples, with a total sample size of 26,513 respondents ${ }^{11}$ (Afrobarometer Network, 2007; Hanusch, 2012).

\footnotetext{
${ }^{9}$ Benin, Botswana, Burkina Faso, Cape Verde, Kenya, Lesotho, Liberia, Madagascar, Malawi, Mali, Mozambique, Namibia, Nigeria, Senegal, South Africa, Tanzania, Uganda, Zambia, Zimbabwe.

${ }^{10}$ The unavailability of earlier or more recent data also implies that it was not possible to add a longitudinal dimension to the analysis.

${ }^{11}$ The Afrobarometer project is based upon a partnership between the Center for Democratic Development (Ghana), the Institute for Empirical Research in Political Economy (Benin), the Institute for Development Studies (Kenya), and the Institute for Justice and Reconciliation (South Africa). It is supported by Michigan State University and the University of Cape Town, as well as by an International Advisory Board of academics. Its methodology is well-elaborated and has been developed since the first Afrobarometer round in 1999. Nevertheless, it should be noted that a measure of caution is still called for when dealing with survey data obtained in the challenging research context of Sub-Saharan Africa.
} 
The Afrobarometer asked respondents about their evaluation of various international actors through the following question: "In your opinion, how much do each of the following do to help your country, or haven't you heard enough to say?", 2 Reponses take the form of a four-point scale $(0=$ do nothing, $1=$ help a little, $2=$ help somewhat, $3=$ help a lot), which is treated here as interval. To answer the comparative research question, a second measure is used which captures the difference in scores accorded to the EU and China by each respondent. This variable hence ranges from -3 (strong preference for China) to 3 (strong preference for the $\mathrm{EU}$ ), with zero indicating a lack of preference.

The first two research questions are answered through a descriptive exploration of the variables capturing perceptions and preference, carried out with SPSS. The third and fourth research questions are approached through a series of multilevel models estimated using MLwiN, with complete case analysis to allow for straightforward model comparison.

\section{Results and discussion}

An important first question concerns the extent to which the EU and China are known to African populations. The most consistent finding to arise from the literature is that 'knowledge of the EU in non-European countries is not very great' (Lucarelli, 2014, p. 7). While it may be expected that this finding will be reproduced for Sub-Saharan Africa, it is less predictable how the EU will fare vis-à-vis China. Compared to the long history of EU engagement, China's large-scale presence in Sub-Saharan Africa is fairly recent. China is, however, renowned for quickly having achieved a high visibility, among others through support for infrastructure projects (Foster, Butterfield, Chen, \& Pushak, 2008).

Table 2: Respondents who felt they knew enough about the EU/China to answer the question (\%)

\begin{tabular}{|l|l|l|l|}
\hline Country & EU & China & Difference \\
\hline Benin & 55.7 & 65 & -9.3 \\
\hline Botswana & 62.3 & 77.6 & $-\mathbf{1 5 . 3}$ \\
\hline Burkina Faso & 61 & 64 & -3 \\
\hline Cape Verde & 76.1 & 84.4 & -8.3 \\
\hline Kenya & 69.8 & 73.7 & -3.9 \\
\hline Lesotho & 53.6 & 81.4 & $\mathbf{- 2 7 . 8}$ \\
\hline Liberia & 85.4 & 90.1 & -4.7 \\
\hline Madagascar & 57 & 60.1 & -3.1 \\
\hline Malawi & 39.2 & 41.7 & -2.5 \\
\hline Mali & 74.2 & 82.8 & -8.6 \\
\hline Mozambique & 56.5 & 68.4 & -11.9 \\
\hline Namibia & 83.3 & 92.7 & -9.4 \\
\hline
\end{tabular}

\footnotetext{
12 This question was asked for 'The European Union' and 'China'. A number of caveats are in place regarding these terms. External perceptions of 'the EU' are most likely also influenced by perceptions of the most salient member states or more general images of Europe as a continent. The question about the EU was, however, preceded by the same question about the former European colonial power, which may be expected to increase the probability that respondents interpreted 'European Union' in a more narrow sense. For 'China', it should be noted that the Chinese presence in Africa consists of a multitude of government-supported activities and independent entrepreneurs. The research presented here cannot distinguish between perceptions of these different components. 'China' should hence be taken to mean the entirety of activities deployed by Chinese actors in Africa, not merely government-supported activities.
} 


\begin{tabular}{|l|l|l|l|}
\hline Nigeria & 65.6 & 66 & -0.4 \\
\hline Senegal & 51.5 & 67.6 & $\mathbf{- 1 6 . 1}$ \\
\hline South Africa & 52.6 & 57.8 & -5.2 \\
\hline Tanzania & 70.4 & 69.8 & +0.6 \\
\hline Uganda & 60.5 & 60 & +0.5 \\
\hline Zambia & 50.3 & 69 & $\mathbf{- 1 8 . 7}$ \\
\hline Zimbabwe & 52 & 74.4 & $\mathbf{- 2 2 . 4}$ \\
\hline Average & $\mathbf{6 1 . 9 5}$ & $\mathbf{7 0 . 8 7}$ & $\mathbf{- 8 . 9 2}$ \\
\hline
\end{tabular}

$\mathrm{N}=26,513$

Source: Afrobarometer Round 4

Table 2 presents the relevant Afrobarometer results. As expected, the EU is not very well known in most countries, with on average almost four out of ten respondents indicating that they do not know enough about the EU to evaluate its help. Results vary quite strongly over countries, ranging from Liberia and Namibia at one extreme (where less than two out of ten gave a 'don't know' answer) to Malawi at the other (where more than 60 per cent of respondents did). The most striking finding, however, comes from the comparison with China. In seventeen out of nineteen countries, China's impact on the country is better known by the population than that of the EU. The difference is often considerable, surpassing 15 per cent in five cases. This indicates that by 2008, China had already built up a clear profile in Africa, while the EU continues to struggle in this field after decades of cooperation.

\section{Positive versus negative evaluations}

China's strong lead over the EU in terms of being known by the population does not necessarily entail a higher degree of support for its activities. To the contrary, the higher percentage of Africans with a clear opinion on China's support might reflect the prevalence of outspokenly negative appraisals. Table 3, therefore, presents the scores given by those who felt they knew enough to evaluate the actors. In all 19 countries combined, 37.8 per cent of respondents indicated that the EU 'helps a lot', the most positive evaluation that could be given. A further 32.2 per cent said the EU 'helps somewhat'. Only 11.3 per cent of the respondents gave the most negative answer of 'does nothing, no help'. On the whole, therefore, the EU's help seems to be quite highly appreciated by African populations ${ }^{13}$. There is quite a bit of variation between countries; while more than a third of South African respondents said the EU does nothing to help their country, in Malawi 62.3 per cent gave the most positive score.

For China, 36.8 per cent of respondents accorded the highest score and 12.5 per cent expressed that it offers 'no help'. As an additional 30.5 per cent said China 'helps somewhat', two thirds of respondents hold a positive or very positive view. This supports earlier evidence that 'African views [on ChinaAfrica links] are not nearly as negative as Western media make out' (Sautman \& Yan, 2009, p. 728). Again, there is some variation between countries, with Uganda and South Africa reporting many critical assessments and Burkina Faso and Lesotho offering very positive appraisals.

\footnotetext{
${ }^{13}$ It should be noted that the timing of the surveys (in 2008) may have negatively affected perceptions of the EU, due to the failed negotiations for EU-ACP Economic Partnership Agreements in the preceding year.
} 
Table 3: Respondents according the most positive and the most negative score to the EU/China (\%)

\begin{tabular}{|l|l|l|l|l|l|l|}
\hline Country & \multicolumn{2}{l}{ "does nothing, no help" } & \multicolumn{2}{l|}{ "helps a lot" } \\
\hline & EU & China & Difference & EU & China & Difference \\
\hline Benin & 8.1 & 5 & +3.1 & 36.2 & 46 & -9.8 \\
\hline Botswana & 4.4 & 4.4 & 0.0 & 49.1 & 54.4 & -5.3 \\
\hline Burkina Faso & 4.4 & 3.5 & +0.9 & 56.7 & 62.7 & -6 \\
\hline Cape Verde & 0.8 & 0.6 & +0.2 & 31.1 & 34.1 & -3 \\
\hline Kenya & 12.7 & 17.4 & -4.7 & 39.8 & 23.6 & $+\mathbf{1 6 . 2}$ \\
\hline Lesotho & 11.4 & 14.3 & -2.9 & 73.4 & 72.8 & +0.6 \\
\hline Liberia & 4.9 & 4.7 & +0.2 & 54.5 & 54.1 & +0.4 \\
\hline Madagascar & 1.4 & 3.9 & -2.5 & 27.6 & 18.2 & +9.4 \\
\hline Malawi & 14 & 13.4 & +0.6 & 62.3 & 52.4 & +9.9 \\
\hline Mali & 8.9 & 7 & +1.9 & 37.6 & 57.3 & $\mathbf{- 1 9 . 7}$ \\
\hline Mozambique & 10.3 & 9.9 & +0.4 & 47.3 & 47.3 & 0.0 \\
\hline Namibia & 10.3 & 12.9 & -2.6 & 31.7 & 26.3 & +5.4 \\
\hline Nigeria & 15.7 & 14.4 & +1.3 & 21.3 & 20.2 & +1.1 \\
\hline Senegal & 15.4 & 11.1 & +4.3 & 40 & 49.4 & -9.4 \\
\hline South Africa & 35.3 & 28.9 & +6.4 & 18 & 14.3 & +3.7 \\
\hline Tanzania & 7.4 & 13.6 & -6.2 & 34.1 & 22.4 & +11.7 \\
\hline Uganda & 9.8 & 28.3 & $\mathbf{1 8 . 5}$ & 32.8 & 10.3 & $+\mathbf{2 2 . 5}$ \\
\hline Zambia & 10.8 & 8.1 & +2.7 & 45.4 & 49.8 & -4.4 \\
\hline Zimbabwe & 18.9 & 18.1 & +0.8 & 28.9 & 28.4 & +0.5 \\
\hline Average & $\mathbf{1 1 . 3}$ & $\mathbf{1 2 . 5}$ & $\mathbf{- 1 . 2}$ & $\mathbf{3 7 . 8}$ & $\mathbf{3 6 . 8}$ & $+\mathbf{1 . 0}$ \\
\hline N & & & & \\
\hline
\end{tabular}

$\mathrm{N}=18,424$ for China and $\mathrm{N}=16,320$ for the $\mathrm{EU}$

Source: Afrobarometer Round 4

Comparing the evaluations of both actors, what is most striking is how similar their levels of popularity appear to be. While there are a number of exceptions (most notably Kenya, Mali and Uganda), in most countries both negative and positive appraisals of the two actors are on a par. ${ }^{14}$

Further insights can be gathered by turning from country averages to individual respondents. Figure 1 presents the distribution of respondents' preferences for the EU or China. By far the most prevalent value is 0 , which represents an equal evaluation of both development partners. Scores indicating a strong preference for one of the two players are quite rare. This clearly sets African public opinion apart from the dominant antagonistic representations in both academic and media accounts, which tend to portray the relationship between traditional and emerging development partners as one of competition and conflict (Mawdsley, 2008; Men \& Barton, 2011). Such binaries are certainly not reflected in African popular perceptions. This could indicate two things: either the approaches of the EU and China are not seen as very different by Africans, or they are seen as different but complementary rather than mutually exclusive.

\footnotetext{
${ }^{14}$ This was confirmed by paired samples t-tests, which showed that the mean scores accorded to the EU and China do not differ significantly at the .05 level in eight out of nineteen countries.
} 


\section{Figure 1: Distribution of preferences for the EU and China}

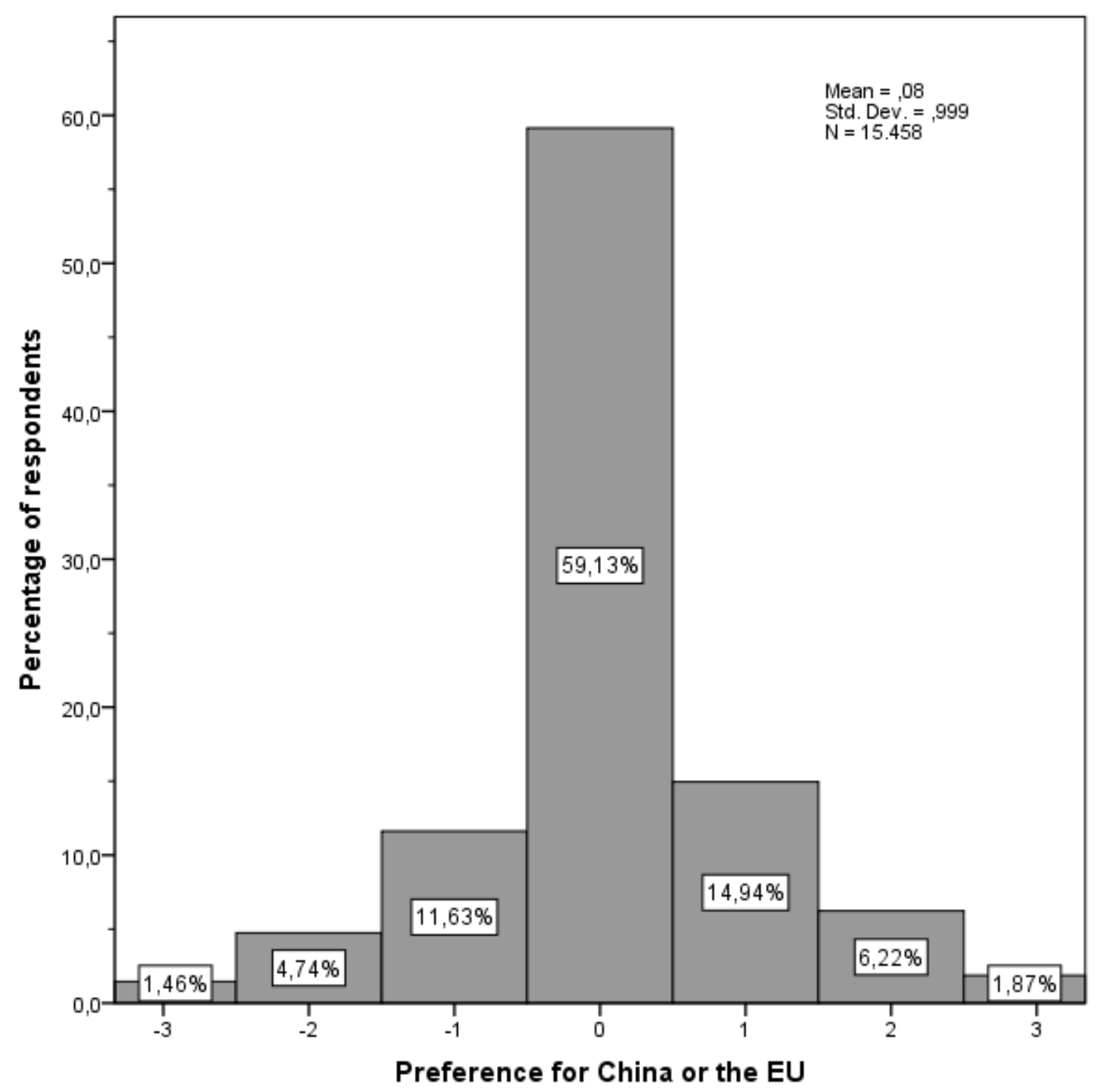

A score of -3 indicates a strong preference for China, a score of 3 a strong preference for the EU

Source: Afrobarometer Round 4

Figure 1 also shows that, across all 19 countries, the EU is slightly more popular, with 23 per cent of respondents expressing a preference for the EU over China, while 17.8 per cent indicated that China helps their country more. The distribution was a lot more skewed within a number of countries, however. For instance, 51 per cent of Ugandan and 39.3 per cent of Namibian respondents preferred the EU, while 28.9 per cent in Mali said China helps more. The EU thus has a slight lead over China overall, but this is not the case within all of the countries under study.

\section{Explaining perceptions}

Moving from description to explanation, the starting point is the issue of multiple levels of explanation raised earlier. To reiterate, the question is whether perceptions are primarily a function of processes at the national level or are mainly formed at the individual level. This can be determined by estimating a null multilevel model, which divides the overall variance into a between-country and a within-country 
component. The ratio of the between-country component to the overall variance (i.e. the intra-class correlation or ICC) provides insight into the importance of the country level in explaining variation in perceptions and preferences. Table 4 presents the ICC for perceptions of the EU and of China, as well as for preferences for one of the two actors.

Table 4: Within-country versus between-country variation in perceptions and preferences

\begin{tabular}{|l|l|l|l|}
\hline & Perceptions of the EU & Perceptions of China & $\begin{array}{l}\text { Preferences for the EU } \\
\text { versus China }\end{array}$ \\
\hline Between-country variance & 0.073 & 0.125 & 0.054 \\
\hline Within-country variance & 0.933 & 0.921 & 0.983 \\
\hline Total variance & 1.006 & 1.046 & 1.037 \\
\hline ICC & $\mathbf{7 . 2 5} \%$ & $\mathbf{1 1 . 9 5 \%}$ & $\mathbf{5 . 2 1} \%$ \\
\hline
\end{tabular}

$\mathrm{N}=11,736$

Source: Afrobarometer Round 4

The results indicate that while there are significant differences in average perceptions between African countries (and the use of a multilevel model is hence warranted), the role of the country level is limited in this specific case ${ }^{15}$. The analysis thus provides evidence for Esteban's argument that there are important differences in perceptions between various groups within the same country. In contrast, there is little support for the conclusion by Sautman and Yan that variation in perceptions is primarily located at the country level, nor for their more specific claim that popular perceptions mainly echo the discourse of national-level politicians. These findings point towards the limits of perceptions analyses focusing on country averages, which have so far formed the dominant approach.

Having determined the relative importance of country-level and individual-level factors for African perceptions of the EU and China, the remainder of this article applies the explanatory framework presented above. The emphasis is on individual-level variables, as this level was found to be the most important for explaining perceptions in the case at hand. It should be noted that certain variables of interest (such as levels of aid by China) could not be included, due to the unavailability of reliable data. Basic descriptive statistics for each of the variables included are given in Table 5. Table 6 presents the series of models estimated. Given the coding of the dependent variable, positive coefficients indicate that a variable is linked to more pro-EU attitudes.

Table 5: Descriptive statistics of the variables included in the multilevel analysis

\begin{tabular}{|l|l|l|l|l|}
\hline Variable & Min - Max & Mean & Std. deviation & Remarks \\
\hline Individual-level & & & & \\
\hline Gender & $0-1$ & 0.43 & 0.495 & $0=$ male, 1 = female \\
\hline Age & $18-90$ & 35.07 & 13.322 & unit = years \\
\hline Income & $0-3$ & 1.39 & 0.961 & \\
\hline Subj. living conditions & $1-5$ & 2.7 & 1.167 & \\
\hline Urban & $0-1$ & 0.44 & 0.497 & $0=$ urban, 1 = rural \\
\hline Education & $0-9$ & 3.78 & 2.001 & \\
\hline Media consumption & $0-12$ & 6.71 & 3.508 & $\begin{array}{l}1 \text { = democracy considered one of top } \\
\text { three priorities }\end{array}$ \\
\hline Democracy priority & $0-1$ & 0.02 & 0.147 & \\
\hline Civil-political HR & $3-15$ & 11.63 & 3.943 & \\
\hline Infrastructure priority & $0-3$ & 0.57 & 0.716 & \\
\hline
\end{tabular}

\footnotetext{
${ }^{15}$ These results only apply to African public opinion. In the case of elite perceptions, one might expect national-
} level variables to play a more substantial role. 


\begin{tabular}{|l|l|l|l|l|}
\hline Influence donors & $0-1$ & 0.34 & 0.474 & $\begin{array}{l}1=\text { international donors and NGOs } \\
\text { have too much influence }\end{array}$ \\
\hline & & & & \multicolumn{1}{|c|}{} \\
\hline Country-level variables & & & 1751.01 & $\begin{array}{l}\text { unit = current US\$ 2008 (World } \\
\text { Bank, 2014) }\end{array}$ \\
\hline GDP per capita & $231-5,747$ & 1516.75 & $\begin{array}{l}\text { unit = years of diplomatic ties with } \\
\text { PRC up to 2008 }\end{array}$ \\
\hline Diplomatic ties & $1-48$ & 31.3 & 12.80 & $\begin{array}{l}\text { Polity Score 2008, Polity IV Project } \\
\text { (Center for Systemic Peace, 2014) }\end{array}$ \\
\hline Democracy score & $(-4)-10$ & 5.3 & 3.79 &
\end{tabular}

$\mathrm{N}=11,736$

Source: Afrobarometer Round 4; Center for Systemic Peace (2014); World Bank (2014)

Model 1 is a null model, which partitions the variance as discussed above (Table 4). Model 2 introduces two general characteristics at the individual level, gender and age. In line with earlier findings, men are found to be significantly more pro-China. While age is initially insignificant, subsequent models indicate that younger people are more supportive of China. This may be linked to the more recent (re)emergence of China as a large-scale development partner.

Model 3 includes further general characteristics at the individual level. It introduces two proxies for respondents' socio-economic status. Following Hanusch (2012, p. 10), 'income' is a composite measure on the basis of a respondent's ownership of a radio, television and motor vehicle. 'Subjective living conditions' is a score that respondents accorded to their own present living conditions. The effect of income is the strongest, with higher scores related to a more pro-China stance. In contrast, a more positive evaluation of one's own living conditions is associated with a stronger preference for the EU. The findings are therefore inconclusive regarding the effect of socio-economic status, indicating that it should be studied in more depth. It should be noted that the two proxies do not allow for distinguishing between people active in different occupations or sectors, which is at the core of some of the arguments outlined earlier. It was hypothesized that some of this variation in respondents' economic interaction with international actors might be captured in whether they live in an urban or a rural area, but the 'urban' variable introduced in Model 3 is consistently insignificant.

The effect of education is significant (though not strongly) and positive, indicating that more highly educated Africans are somewhat more pro-EU. The last variable introduced in Model 3 is 'media consumption', which captures how frequently respondents get news from radio, television and newspaper sources. There is only a weak overall effect, with those who consult media sources more often expressing a slightly more pro-EU stance. However, as the content of media messages varies per country, it is not surprising that no strong effect is found for all 19 countries combined. A later model will therefore allow the effect of media-consumption to vary over countries. 
Table 6: Multilevel analysis of the determinants of African popular preferences for the EU versus China

\begin{tabular}{|c|c|c|c|c|c|c|c|c|c|c|c|c|}
\hline \multirow[b]{2}{*}{ Fixed part } & \multicolumn{2}{|c|}{ Model 1} & \multicolumn{2}{|c|}{ Model 2} & \multicolumn{2}{|c|}{ Model 3} & \multicolumn{2}{|c|}{ Model 4} & \multicolumn{2}{|c|}{ Model 5} & \multicolumn{2}{|c|}{ Model 6} \\
\hline & Par. & S.E. & Par. & S.E. & Par. & S.E. & Par. & S.E. & Par. & S.E. & & \\
\hline Intercept & 0.056 & 0.054 & 0.011 & 0.061 & -0.098 & 0.068 & $-0.189 * *$ & 0.079 & -0.095 & 0.168 & -0.111 & 0.190 \\
\hline \multicolumn{13}{|l|}{ Individual-level } \\
\hline Gender & & & $0.033^{*}$ & 0.019 & $0.037 * *$ & 0.019 & $0.040 * *$ & 0.019 & $0.040 * *$ & 0.019 & $0.038^{* *}$ & 0.019 \\
\hline Age & & & 0.001 & 0.001 & $0.002 * *$ & 0.001 & $0.002 * *$ & 0.001 & $0.002 * *$ & 0.001 & $0.002 * *$ & 0.001 \\
\hline Income & & & & & $-0.027 * *$ & 0.012 & $-0.028 * *$ & 0.012 & $-0.028 * *$ & 0.012 & $-0.025 * *$ & 0.012 \\
\hline Subjective living conditions & & & & & 0.013 & 0.008 & $0.015^{*}$ & 0.008 & $0.014^{*}$ & 0.008 & $0.014^{*}$ & 0.008 \\
\hline Urban & & & & & -0.015 & 0.021 & -0.017 & 0.021 & -0.017 & 0.021 & -0.019 & 0.021 \\
\hline Education & & & & & $0.012 * *$ & 0.006 & $0.011^{*}$ & 0.006 & $0.011^{*}$ & 0.006 & 0.010 & 0.006 \\
\hline Media consumption & & & & & $0.006^{*}$ & 0.004 & 0.006 & 0.004 & 0.006 & 0.004 & 0.005 & 0.006 \\
\hline Democracy priority & & & & & & & $0.178^{* * *}$ & 0.063 & $0.177 * * *$ & 0.063 & $0.184 * * *$ & 0.063 \\
\hline Civil-political human rights & & & & & & & $0.006^{* *}$ & 0.003 & $0.006^{* *}$ & 0.003 & $0.007 * *$ & 0.003 \\
\hline Infrastructure priority & & & & & & & -0.003 & 0.013 & -0.003 & 0.013 & -0.004 & 0.013 \\
\hline Donor influence & & & & & & & $0.051 * *$ & 0.020 & $0.051 * *$ & 0.020 & $0.052 * *$ & 0.020 \\
\hline \multicolumn{13}{|l|}{ Country-level } \\
\hline GDP per capita & & & & & & & & & 0.000 & 0.000 & 0.000 & 0.000 \\
\hline Diplomatic ties & & & & & & & & & 0.001 & 0.004 & 0.002 & 0.004 \\
\hline Democracy score & & & & & & & & & $-0.030 * *$ & 0.014 & $-0.029 *$ & 0.016 \\
\hline \multirow{2}{*}{\multicolumn{13}{|c|}{ Random Part }} \\
\hline & & & & & & & & & & & & \\
\hline Residual variance & $0.983 * * *$ & 0.013 & $0.982 * * *$ & 0.013 & $0.981 * * *$ & 0.013 & $0.980 * * *$ & 0.013 & $0.980 * * *$ & 0.013 & $0.977 * * *$ & 0.013 \\
\hline Random intercept & $0.054 * * *$ & 0.018 & $0.054 * * *$ & 0.018 & $0.051 * * *$ & 0.017 & $0.051 * * *$ & 0.017 & $0.040 * * *$ & 0.014 & $0.064 * * *$ & 0.024 \\
\hline Random MediaConsumption & & & & & & & & & & & $0.000 * *$ & 0.000 \\
\hline ICC & \multicolumn{2}{|c|}{0.052} & \multicolumn{2}{|c|}{0.052} & \multicolumn{2}{|c|}{0.049} & \multicolumn{2}{|c|}{0.049} & \multicolumn{2}{|c|}{0.039} & \multicolumn{2}{|c|}{0.061} \\
\hline Deviance & 33166.531 & & 33162.373 & & 33147.174 & & 33127.762 & & 33123.288 & & 33103.116 & \\
\hline
\end{tabular}

$\mathrm{N}$ countries $=19, \mathrm{~N}$ respondents $=11,736$

$(* \mathrm{p}<.1, * * \mathrm{p}<.05, * * * \mathrm{p}<.01)$ 
Model 4 introduces several relation-specific characteristics. The dummy 'democracy priority' captures whether respondents regard democracy as one of the top three problems their government should address. 'Civil-political human rights' indicates to what extent the respondent finds freedom of organization, press and expression desirable. 'Influence donors' is a dummy that takes the value of one for respondents who expressed that international donors and NGOs have too much influence over their government. Finally, 'infrastructure priority' captures the extent to which the development of infrastructure (transportation, communications, roads, electricity and water supply) are considered among the top three priorities for the government. It is hypothesized that respondents who attach major importance to democracy and to civil and political human rights will be more pro-EU. In contrast, Africans who prioritize infrastructure development and who feel donors have too much influence are expected to be more favourable towards China. The inclusion of these variables is thus aimed at determining whether preferences are also influenced by the more abstract development discourses of China and the EU.

The findings show that this indeed seems to be the case. Respondents who name democracy as a top priority for their country are significantly more pro-EU than those who do not. This observation is further backed by the (somewhat weaker) relationship between support for civil and political human rights and a more pro-EU stance. China's approach to development co-operation, in contrast, is less clearly reflected in the perceptions of Africans. Views on donor influence are found to be related to perceptions of the EU and China but, contrary to expectations, respondents who find international donors and NGO's have too much influence over their government are less, not more, in favour of China. Respondents who express a greater need for infrastructure development are not significantly more pro-China than others.

Model 5 subsequently brings in three characteristics at the country level, in an attempt to explain part of the country-level variance. Two of these variables, GDP per capita and 'democracy score' (measured on a 15-point scale by the Polity IV Project), are general characteristics of a country. The variable 'diplomatic ties' is relation-specific, capturing for how many years each country had had diplomatic ties with China up to 2008. This variable, which varies from just one year in the case of Malawi to 48 years in the case of Mali, is used here as a proxy for the strength of the historical relationship with China. The results indicate that differences in average preferences between African countries are not significantly related to differences in level of economic development, nor to variations in the historical ties with China. In contrast, the level of democracy does appear to play a role, with attitudes being significantly more pro-EU in less democratic countries. Like the highly significant effect of support to democracy at the individual level, this may indicate an awareness of the focus on democracy in the EU's development discourse.

In Model 6, the influence of media consumption is allowed to vary over countries, to reflect the fact that media messages may be more pro-China in some countries and more pro-EU in others. While the inclusion of this random term significantly improves the fit of the model, the parameter estimate indicates that the variance in the effect of media consumption is very small. Finally, it should also be noted that the overall decrease in residual variance throughout the series of models is limited, indicating that substantial explanatory work remains to be done. 


\section{Conclusion}

This article has argued that the burgeoning literature on external perceptions of the EU is in need of a comparative perspective, as well as a stronger focus on explanation. In an attempt to fill these gaps, it focused on the neglected region of Sub-Saharan Africa. To guide the analysis, an explanatory framework was introduced that combines arguments from analyses of African perceptions of China with insights from the broader literature on 'traditional' versus 'emerging' development partners. Two key aspects were highlighted: the distinction between general and relation-specific characteristics, and the issue of multiple levels of explanation. The latter in particular indicated that existing work on EU external perceptions, which is strongly empirically driven, needs to be complemented by a more thorough reflection on the origin and nature of perceptions.

The exploration of Afrobarometer data from 19 countries indicated that, first, the EU is not very well known among Sub-Saharan African populations. China has succeeded in achieving a clearer profile in almost all countries in the study, and has done this in a very limited amount of time. Despite its longer engagement, the EU is struggling in terms of its visibility. Second, the EU enjoys broad-based support as a development partner, but so does China. Third, African evaluations of EU versus Chinese support do not at all reflect the antagonistic representations that are dominant in much of the scholarly literature. African populations appear to see engagement by traditional and emerging development partners as complementary rather than mutually exclusive.

The final section presented an application of the explanatory framework. The findings do not support past claims that popular perceptions of development partners mainly mirror national-level variables, indicating instead that preferences are a function primarily of individual experiences and outlooks. Differences in perceptions between countries, while relatively limited, do remain significant. On the individual level, both general characteristics of respondents and relation-specific attitudes were found to have an impact. While women and more highly educated Africans are more pro-EU, the impact of socio-economic status on preferences is complex and in need of further exploration. Interestingly, the EU's insistence on democratic development seems to be recognized by African public opinion, as those who attach greater importance to democracy and civil-political human rights express a significantly stronger preference for the EU.

To conclude, a number of avenues for future research can be indicated. First, it would be highly interesting to study how perceptions have evolved since 2008. The data analysed here capture African popular perceptions of the Chinese engagement at a fairly early stage. Perceptions of China may since have improved (as results of cooperation have further materialised) or deteriorated (due to perceived negative effects). For the EU, the Eurozone crisis may have impacted negatively on external perceptions, as has been demonstrated for other regions (e.g. Chaban \& Magdalina, 2014). Unfortunately, such a longitudinal analysis of African popular perceptions is not possible at the moment, due to the unavailability of more recent survey data. A second avenue for future research lies in further study of EU external perceptions in crucial yet neglected regions, such as the southern and eastern neighbours. This geographical focus should be complemented by a comparative approach, relating external perceptions of the EU to those of other salient international actors in each particular 
context. Finally, and perhaps most importantly, the analytical underpinnings of external perceptions research deserve much stronger attention. A solid conceptual and explanatory framework, for which this article has sought to indicate a number of key dimensions, is not only vital for gaining deeper insight into external images of specific international actors, but also for exploring the opportunities and limits of this field of study. 


\section{Bibliography}

Afrobarometer Network (2014) 'Afrobarometer Database'. (Pretoria: IDASA).

Bacon, P. and Kato, E. (2013) 'Potential Still Untapped: Japanese Perceptions of the European Union as an Economic and Normative Power'. Baltic Journal of European Studies, Vol. 3, No. 3, pp. 59-84.

Brautigam, D. (2011) 'Aid 'with Chinese Characteristics': Chinese Foreign Aid and Development Finance Meet the OECD-DAC Aid Regime'. Journal of International Development, Vol. 23, pp. 752-64.

Center for Systemic Peace (2014) 'Polity IV Project Dataset'. (Vienna (Virginia, USA): Center for Systemic Peace).

Chaban, N. and Elgström, O. (2014) 'The Role of the EU in an Emerging New World Order in the Eyes of the Chinese, Indian and Russian Press'. Journal of European Integration, Vol. 36, No. 2, pp. 170-88.

Chaban, N., Elgström, O., Kelly, S. and Lai, S.-Y. (2013) 'Images of the EU beyond its Borders: IssueSpecific and Regional Perceptions of European Union Power and Leadership'. Journal of Common Market Studies, Vol. 51, No. 3, pp. 433-51.

Chaban, N. and Holland, M. (eds.) (2013) Europe and Asia: Perceptions from Afar (Baden-Baden: Nomos).

Chaban, N. and Magdalina, A.-M. (2014) 'External Perceptions of the EU during the Eurozone Sovereign Debt Crisis'. European Foreign Affairs Review, Vol. 19, No. 2, pp. 195-220.

Elgström, O. (2007) 'Outsiders' Perceptions of the European Union in International Trade Negotiations'. Journal of Common Market Studies, Vol. 45, No. 4, pp. 949-67.

Elgström, O. (2010) 'Partnership in Peril? Images and Strategies in EU-ACP economic partnership agreement negotiations'. In Lucarelli, S. and Fioramonti, L. (eds.) External Perceptions of the European Union as a Global Actor (Oxon: Routledge).

Esteban, M. (2010) 'A Silent Invasion? African Views on the Growing Chinese Presence in Africa: The Case of Equataorial Guinea'. African and Asian Studies, Vol. 9, pp. 232-51.

Fioramonti, L. and Kimunguyi, P. (2011) 'Public and Elite Views on Europe vs. China in Africa'. The International Spectator: Italian Journal of International Affairs, Vol. 46, No. 1, pp. 69-82.

Fioramonti, L. and Olivier, G. (2007) 'Altruism or Self-Interest? An Exploratory Study of the EU's External Image in South Africa'. European Foreign Affairs Review, Vol. 12, No. 3, pp. 40119.

Fioramonti, L. and Poletti, A. (2008) 'Facing the Giant: Southern Perspectives on the European Union'. Third World Quarterly, Vol. 29, No. 1, pp. 167-80.

Foster, V., Butterfield, W., Chen, C. and Pushak, N. (2008) Building Bridges: China's Growing Role as Infrastructure Financier for Africa (Washington: The World Bank).

Hanusch, M. (2012) 'African Perspectives on China-Africa: Modelling Popular Perceptions and their Economic and Political Determinants'. Oxford Development Studies, Vol. 40, No. 4, pp. $492-$ 516.

Holslag, J. (2011) 'China's Evolving Behaviour in Africa and the Options of Cooperation with Europe'. Journal of Current Chinese Affairs, Vol. 4, pp. 3-16. 
Jain, R.K. and Pandey, S. (2013) 'Indian Elites and the EU as a Normative Power'. Baltic Journal of European Studies, Vol. 3, No. 3, pp. 105-26.

Kelly, S. and Smith, N.R. (2013) 'The EU's Reaction to the Arab Spring: External Media Portrayals in China, India and Russia'. European Foreign Affairs Review, Vol. 18, No. 2, pp. 217-34.

Larsen, H. (2014) 'The EU as a Normative Power and the Research on External Perceptions: The Missing Link'. Journal of Common Market Studies, Vol. 52, No. 4, pp. 896-910.

Lucarelli, S. (2014) 'Seen from the Outside: The State of the Art on the External Image of the EU'. Journal of European Integration, Vol. 36, No. 1, pp. 1-16.

Lucarelli, S. and Fioramonti, L. (eds.) (2010) External Perceptions of the European Union as a Global Actor (Oxon: Routledge).

Mawdsley, E. (2008) 'Fu Manchu versus Dr Livingstone in the Dark Continent? Representing China, Africa and the West in British broadsheet newspapers'. Political Geography, Vol. 27, pp. 50929.

Mawdsley, E. (2012) From Recipients to Donors: Emerging Powers and the Changing Development Landscape (London: Zed Books).

Mayer, H. and Zielonka, J. (2012) 'Special issue 'Europe as a Global Power: View from Outside". Perspectives, Vol. 20, No. 2, pp. 5-129.

Men, J. and Barton, B. (2011) 'Introduction: China and the EU in Africa: Changing Concepts and Changing Policies'. In Men, J. and Barton, B. (eds.) China and the European Union in Africa: Partners or Competitors? (Farnham: Ashgate).

Misík, M. (2013) 'How can perception help us to understand the dynamic between EU member states? The state of the art'. Asia Europe Journal, Vol. 11, pp. 445-63.

Ogunleye, E.K. (2011) 'The EU and China: Friends or Foes for Sustainable Regional Infrastructure Development and Resource Extraction in Africa?'. In Men, J. and Barton, B. (eds.) China and the European Union in Africa: Partners or Competitors? (Farnham: Ashgate).

Olivier, G. and Fioramonti, L. (2010) 'The emerging 'global south': the EU in the eyes of India, Brazil and South Africa'. In Lucarelli, S. and Fioramonti, L. (eds.) External Perceptions of the European Union as a Global Actor (Oxon: Routledge).

Park, Y.J. (2013) 'Perceptions of Chinese in Southern Africa: Constructions of the "Other" and the Role of Memory'. African Studies Review, Vol. 56, No. 1, pp. 131-53.

Sautman, B. and Yan, H. (2009) 'African Perspectives on China-Africa Links'. The China Quarterly, Vol. 199, pp. 728-59.

Shen, S. and Taylor, I. (2012) 'Ugandan Youths' Perceptions of Relations with China'. Asian Perspective, Vol. 36, pp. 693-723.

Sicurelli, D. (2010) 'Regional Partners? Perceptions and criticisms at the African Union'. In Lucarelli, S. and Fioramonti, L. (eds.) External Perceptions of the European Union as a Global Actor (Oxon: Routledge).

Stumbaum, M.-B.U. (2013) "Apples and oranges'? Comparing Chinese and European Perspectives on the EU as a Security Actor'. European Foreign Affairs Review, Vol. 18, No. 3, pp. 355-72.

Sylvanus, N. (2013) 'Chinese Devils, the Global Market, and the Declining Power of Togo's NanaBenzes'. African Studies Review, Vol. 56, No. 1, pp. 65-80.

Torney, D. (2014) 'External Perceptions and EU Foreign Policy Effectiveness: The Case of Climate Change'. Journal of Common Market Studies, DOI: 10.1111/jcms.12150. 
Tsuruoka, M. (2008) 'How External Perceptions of the European Union are Shaped: Endogenous and Exogenous Sources'. Paper presented at the GARNET Conference The EU in International Affairs, Brussels, 24-26 april.

World Bank (2014) 'World DataBank - World Development Indicators'. (Washington: World Bank).

Bacon, Paul, \& Kato, Emi. (2013). Potential Still Untapped: Japanese Perceptions of the European Union as an Economic and Normative Power. Baltic Journal of European Studies, 3(3), 59-84.

Brautigam, Deborah. (2011). Aid 'with Chinese Characteristics': Chinese Foreign Aid and Development Finance Meet the OECD-DAC Aid Regime. Journal of International Development, 23, 752-764.

Center for Systemic Peace. (2014). Polity IV Project Dataset. Retrieved from: http://www.systemicpeace.org/inscrdata.html

Chaban, Natalia, \& Elgström, Ole. (2014). The Role of the EU in an Emerging New World Order in the Eyes of the Chinese, Indian and Russian Press. Journal of European Integration, 36(2), 170188.

Chaban, Natalia, Elgström, Ole, Kelly, Serena, \& Lai, Suet-Yi. (2013). Images of the EU beyond its Borders: Issue-Specific and Regional Perceptions of European Union Power and Leadership. Journal of Common Market Studies, 51(3), 433-451.

Chaban, Natalia, \& Holland, Martin (Eds.). (2013). Europe and Asia: Perceptions from Afar. BadenBaden: Nomos.

Chaban, Natalia, \& Magdalina, Ana-Maria. (2014). External Perceptions of the EU during the Eurozone Sovereign Debt Crisis. European Foreign Affairs Review, 19(2), 195-220.

Elgström, Ole. (2007). Outsiders' Perceptions of the European Union in International Trade Negotiations. Journal of Common Market Studies, 45(4), 949-967.

Elgström, Ole. (2010). Partnership in Peril? Images and Strategies in EU-ACP economic partnership agreement negotiations. In S. Lucarelli \& L. Fioramonti (Eds.), External Perceptions of the European Union as a Global Actor (pp. 137-149). Oxon: Routledge.

Esteban, Mario. (2010). A Silent Invasion? African Views on the Growing Chinese Presence in Africa: The Case of Equataorial Guinea. African and Asian Studies, 9, 232-251.

Fioramonti, Lorenzo, \& Kimunguyi, Patrick. (2011). Public and Elite Views on Europe vs. China in Africa. The International Spectator: Italian Journal of International Affairs, 46(1), 69-82.

Fioramonti, Lorenzo, \& Olivier, Gerrit. (2007). Altruism or Self-Interest? An Exploratory Study of the EU's External Image in South Africa. European Foreign Affairs Review, 12(3), 401-419.

Fioramonti, Lorenzo, \& Poletti, Arlo. (2008). Facing the Giant: Southern Perspectives on the European Union. Third World Quarterly, 29(1), 167-180.

Foster, Vivien, Butterfield, William, Chen, Chuan, \& Pushak, Nataliya. (2008). Building Bridges: China's Growing Role as Infrastructure Financier for Africa Trends and Policy Options. Washington DC: The World Bank.

Hanusch, Marek. (2012). African Perspectives on China-Africa: Modelling Popular Perceptions and their Economic and Political Determinants. Oxford Development Studies, 40(4), 492-516.

Holslag, Jonathan. (2011). China's Evolving Behaviour in Africa and the Options of Cooperation with Europe. Journal of Current Chinese Affairs, 4, 3-16.

Jain, Rajendra K., \& Pandey, Shreya. (2013). Indian Elites and the EU as a Normative Power. Baltic Journal of European Studies, 3(3), 105-126.

Kelly, Serena, \& Smith, Nicholas Ross. (2013). The EU's Reaction to the Arab Spring: External Media Portrayals in China, India and Russia. European Foreign Affairs Review, 18(2), 217-234.

Larsen, Henrik. (2014). The EU as a Normative Power and the Research on External Perceptions: The Missing Link. Journal of Common Market Studies, 52(4), 896-910. doi: 10.1111/jcms.12109 
Lucarelli, Sonia. (2014). Seen from the Outside: The State of the Art on the External Image of the EU. Journal of European Integration, 36(1), 1-16.

Lucarelli, Sonia, \& Fioramonti, Lorenzo (Eds.). (2010). External Perceptions of the European Union as a Global Actor. Oxon: Routledge.

Mawdsley, Emma. (2008). Fu Manchu versus Dr Livingstone in the Dark Continent? Representing China, Africa and the West in British broadsheet newspapers. Political Geography, 27, 509529.

Mawdsley, Emma. (2012). From Recipients to Donors: Emerging Powers and the Changing Development Landscape. London: Zed Books.

Mayer, Hartmut, \& Zielonka, Jan. (2012). Special issue 'Europe as a Global Power: View from Outside'. Perspectives: Review of International Affairs, 20(2), 5-129.

Men, Jing, \& Barton, Benjamin. (2011). Introduction: China and the EU in Africa: Changing Concepts and Changing Policies. In J. Men \& B. Barton (Eds.), China and the European Union in Africa: Partners or Competitors? (pp. 1-22). Farnham: Ashgate.

Misík, Matús. (2013). How can perception help us to understand the dynamic between EU member states? The state of the art. Asia Europe Journal, 11, 445-463.

Ogunleye, Eric Kehine. (2011). The EU and China: Friends or Foes for Sustainable Regional Infrastructure Development and Resource Extraction in Africa? In J. Men \& B. Barton (Eds.), China and the European Union in Africa: Partners or Competitors? (pp. 227-243). Farnham: Ashgate.

Olivier, Gerrit, \& Fioramonti, Lorenzo. (2010). The emerging 'global south': the EU in the eyes of India, Brazil and South Africa. In S. Lucarelli \& L. Fioramonti (Eds.), External Perceptions of the European Union as a Global Actor (pp. 105-119). Oxon: Routledge.

Park, Yoon Jung. (2013). Perceptions of Chinese in Southern Africa: Constructions of the "Other" and the Role of Memory. African Studies Review, 56(1), 131-153.

Sautman, Barry, \& Yan, Hairong. (2009). African Perspectives on China-Africa Links. The China Quarterly, 199, 728-759.

Shen, Simon, \& Taylor, Ian. (2012). Ugandan Youths' Perceptions of Relations with China. Asian Perspective, 36, 693-723.

Sicurelli, Daniel. (2010). Regional Partners? Perceptions and criticisms at the African Union. In S. Lucarelli \& L. Fioramonti (Eds.), External Perceptions of the European Union as a Global Actor (pp. 180-194). Oxon: Routledge.

Stumbaum, May-Britt U. (2013). 'Apples and oranges'? Comparing Chinese and European Perspectives on the EU as a Security Actor. European Foreign Affairs Review, 18(3), 355-372.

Sylvanus, Nina. (2013). Chinese Devils, the Global Market, and the Declining Power of Togo's NanaBenzes. African Studies Review, 56(1), 65-80.

Torney, Diarmuid. (2014). External Perceptions and EU Foreign Policy Effectiveness: The Case of Climate Change. Journal of Common Market Studies.

Tsuruoka, Michito. (2008). How External Perceptions of the European Union are Shaped: Endogenous and Exogenous Sources. Paper presented at the GARNET Conference The EU in International Affairs, Brussels.

World Bank. (2014). World DataBank - World Development Indicators. Retrieved from: http://databank.worldbank.org/data/views/variableSelection/selectvariables.aspx?source=w orld-development-indicators 